\title{
Study of Blood Serum Biochemical Profile and Pathological Changes in Haemonchosis Experimentally Induced in Goats
}

\author{
Ezatullah Jaheed \\ Department of Para Clinic, Faculty of Veterinary Science, Kabul University, Kabul, Afghanistan
}

Email address:

jaheedezatullah@yahoo.com

To cite this article:

Ezatullah Jaheed. Study of Blood Serum Biochemical Profile and Pathological Changes in Haemonchosis Experimentally Induced in Goats. American Journal of BioScience. Vol. 9, No. 3, 2021, pp. 95-104. doi: 10.11648/j.ajbio.20210903.14

Received: May 21, 2021; Accepted: June 7, 2021; Published: June 15, 2021

\begin{abstract}
Haemonchus contortus (H. contortus) parasite causes various functional derangements in the host body. This experimental study was established to appraise the remedial effect of Balanites aegyptiaca fruit's ethanolic extract (BAF-EE) on experimentally induced haemonchosis in goats. Blood serum biochemical parameters and pathological changes were perused. Twelve male goats were randomly divided into 4 equal groups, G1 (infected-untreated), G2 (infected- BAF-EE treated), G3 (infected-albendazole treated) and G4 (uninfected-BAF-EE treated). Experimental infection was conducted with a single oral dose of $10 \mathrm{x}^{3}$ infective third larval stage (L3) of $H$. contortus at 0 -time, whereas treatment with BAF-EE and albendazole was given at a single oral dose of $9 \mathrm{~g}$ and $5 \mathrm{mg} / \mathrm{kg}$ body wieght respectively in the $5^{\text {th }}$ week post infection (PI). Blood samples were drawn on zero time, $3^{\text {rd }}$ week PI and then biweekly till the $9^{\text {th }}$ week for serum biochemical analyses. At the end of the experiment, all animals were slaughtered to estimate histopathological alterations in the abomasal and hepatic tissues. Serum biochemistry of infected animals showed significant depression of total serum protein (TP), albumin, albumin/globulin $(\mathrm{A} / \mathrm{G})$ ratio, total antioxidant capacity (TAC) and calcium (Ca) levels compared to uninfected goats. Significant elevation was observed in values of aspartate aminotransferase (AST), alanine aminotransferase (ALT), gammaglutamyl transferase $(\gamma \mathrm{GT})$, cholesterol, urea and creatinine of infected animals, while no significant differences were recorded in levels of inorganic phosphorus $(\mathrm{P})$, potassium $(\mathrm{K})$, sodium $(\mathrm{Na})$, chloride $(\mathrm{Cl})$ and total iron binding capacity (TIBC). Histopathological studies conducted on abomasa of infected-untreated animals revealed inflammation, necrosis, petechial hemorrhages and intense cellular infiltration. Liver showed bile duct hyperplasia, degeneration of hepatocytes and cell infiltration. Histopathological alterations in tissues of infected - treated animals were lower in intensity than those of infecteduntreated goats. Results of the present experiment demonstrated that BAF-EE has an anti-parasitic and hepatoprotective effects as well as it improves serum biochemical alterations and oxidative stress in goats infected with $H$. contortus parasite. The present findings nominate the use of this plant as a novel safe natural anthelmintic agent.
\end{abstract}

Keywords: Haemonchosis, Goats, Blood Serum Biochemistry, Pathology, Balanites aegyptiaca

\section{Introduction}

Infection of small ruminants (sheep and goats) with $H$. contortus parasite has detrimental effect on their well-being, causing anaemia, loss of body weight and productivity [4] and may cause death due to haemorrhages in the gastrointestinal tract of the animal [53]. The parasite induces decreased appetite and digestibility of food as well as diversion of nutrients from production sites toward the repair of tissue-damage, which lead to disturbances in the hematological, blood biochemical and antioxidant parameters of the host $[3,12,15,37,55]$.

When inhabiting the abomasum of sheep and goats, the parasite mainly affects the abomasal mucosa, consuming blood of the host and causing pathological alterations such as hyperplasia of the abomasal epithelium, edema of the mucosa and submucosa, hemorrhages, elevated abomasal $\mathrm{pH}$ and necrosis of different parts of the abomasum [6, 7]. On the other hand, development of resistance to most of the commercially available anthelmintic drugs, besides the 
unavailability of these drugs to the poor farmers of developing countries opened way for using herbal remedies as alternative anthelmintics [36]. Among these, B. aegyptiaca (L.) Delile, a well-known medicinal plant present in tropical and subtropical regions of the world.

Balanites aegyptiaca (L.) Delile is a species of a tree, belonging to the family Balanitaceae, which has compound leaves, greenish yellow flowers, and brown or pale brown fruit known as desert date [16]. Its traditional roles and values were well known for thousands of years as fruits were found in cemeteries of the $12^{\text {th }}$ Egyptian dynasty. Recently, numerous studies reported that $B$. aegyptiaca contains wide variety of compounds, which show a wide range of biological and pharmacological properties such as antioxidant, antiinflammatory, antimicrobial, antidiabetic and cytotoxic activities $[3,16,21,36,44]$.

The objective of the present study was to evaluate the curative anthelmintic suppressant effects of the medicinal plant $B$. aegyptiaca fruit's mesocarp ethanolic extract (BAF-EE) on experimentally induced $H$. contortus infection in goats in comparison with the effects of albendazole as a broad spectrum anthelmintic. Evaluation of blood serum biochemical parameters, gross and histopathological alterations in abomasum and liver were considered in this study.

\section{Materials and Methods}

\subsection{Fruit Procurement and BAF-EE Preparation}

B. aegyptiaca fruit was procured from a local market and was verified scientifically. The ethanolic extract of the fruits' mesocarp (BAF-EE) was prepared as described [66]. The fruit mesocarp was macerated several times with $70 \%$ ethyl alcohol at room temperature for 1 week then filtered. The solvent was removed under vacuum at $40^{\circ} \mathrm{C}$ by rotary evaporator and the extract was stored at $-4^{\circ} \mathrm{C}$.

\subsection{Genesis of Infective Larval Dose of H. Contortus Parasite (L3)}

Based on methods appear in the literature [35, 57], the female worms were used to obtain the infective third larval stage (L3) of $H$. contortus worms in a suitable culture. The L3 were obtained by means of Baerman Wetzal funnel technique and the obtained larvae were counted and their number in the total amount of the solution was calculated using standard formula [62].

$$
\text { Total number of larvae }=\frac{\text { No. of larvae counted in petri dish } \times \text { Total volume of solution }}{\text { Amount of solution transfered to petri dish }}
$$

A goat kid proved to be free from internal parasites was inoculated orally with a dose of $10,000 \mathrm{~L}_{3}$ in $10 \mathrm{ml}$ physiological saline as recommended $[29,37]$ and kept as donor animal. Subsequently, the donor animal was used as a source for getting monospecific L3 to induce infection in the experimental animals.

\subsection{Experimental Animals and Design}

A total of 12 male, six to nine months old goats (Capra hircus), weighing $15-20 \mathrm{Kg}$., apparently healthy and free of internal parasites were used. The animals were kept indoor in a barn and were fed on a balanced ration, offered fresh tape water and kept under close observation for 30 days to acclimate together before experimentation. They were randomly divided into four experimental groups, each of three animals, as group $1(\mathrm{G} 1)$, group $2(\mathrm{G} 2)$, group $3(\mathrm{G} 3)$ and group 4 (G4). Animals in G1 were infected orally with 10,000 L3 of $\mathrm{H}$. contortus and served as control positive group. Animals in G2 were infected with L3 as mentioned above and administrated BAF-EE at an oral dose of $9 \mathrm{~g} / \mathrm{Kg}$ body weight. Animals in G3 were infected as mentioned above and treated with a single oral dose of albendazole at the rate of $5 \mathrm{mg} / \mathrm{kg}$ body weight in the form of $2.5 \%$ oral suspension as recommended by the manufacturer company (the Veterinary Division of EVA Pharma, Cairo, Egypt). Animals in G4 were kept as normal control group (uninfected- untreated group). Each group of the experimental animals was kept isolated in a separate ban during the period of the experiment which persisted for 9 weeks. The infection was confirmed on the 3rd week post infection (PI) by fecal analysis.

\subsection{Blood Serum Biochemical Assays}

Samples for serum biochemical analyses were obtained from whole blood collected from the jugular vein of each animal into plain vacutainer tubes at zero-time of the experiment, and at the 3rd week PI, then every other week PI until the end of the experiment. Sera were kept frozen at $\left(-20^{\circ} \mathrm{C}\right)$ until used. Blood serum biochemical parameters were determined utilizing T 80 UV/VIS spectrophotometer (England) and standard commercial test kits for each component; total protein (TP) was determined according to the Biuret method [27], albumin was assayed by the Bromo cresol green method [17] and value of total globulins was calculated by subtracting albumin concentration from total proteins [14]. Activities of aspartate aminotransferase (AST) and alanine aminotransferase (ALT) enzymes were evaluated according to the method described by Trinder [56], while that of gamma-glutamyl transferase $(\gamma \mathrm{GT})$ was measured according to the method explained by Szasz [63]. Levels of serum total cholesterol and triglycerides were determined as described in earlier literatures [5, 23]. Total bilirubin was measured by direct spectrophotometric method [38]. Serum creatinine value was obtained using method explained by Houot [34] and urea level was determined using calorimetric method [50]. Serum total antioxidant capacity (TAC) was estimated according to the confidence of Koracevi et al. [42].

Calcium and Phosphorus values were obtained by rapid calorimetric methods [25, 26]. Sodium, potassium and chloride values were estimated according to the methods appear in the literature $[31,58,65]$. Total iron binding 
capacity (TIBC) was determined following the view of Fairbanks and Klee [22].

\subsection{Pathological Observations}

\subsubsection{Gross Lesions}

All experimental animals were necropsied and gross pathological alterations were recorded.

\subsubsection{Assessment of Histopathological Lesions}

Tissue specimens from abomasa and livers were sliced at a size of $0.5-1 \mathrm{~cm}$ and preserved into $10 \%$ neutral buffered formalin. Specimens then were standardly processed for routine histopathological examination [52]. Microtomy was performed by rotatory microtome (Baired and Totlock, England), and sections of 5 microns thickness were prepared and stained with haematoxylin and eosin (H\&E).

\subsection{Statistical Analysis}

All data were subjected to statistical analysis according to the viewpoint of Snedecor and Cochran [61], using SPSS (version 10) computer program. Statistical analysis included calculation of the mean and standard error of the mean (mean \pm SE). Differences between control and treated groups were tested for significance using one-way analysis of variance (ANOVA), and Duncan's multiple range test to detect the significance among means in between different experimental groups and days. Differences were considered significant at $\mathrm{P}$ $\leq 0.05$ level of probability.

\section{Results}

\subsection{Blood Serum Biochemical Analysis}

Mean values of blood serum constituents of normal control animals (at 0 time) were fluctuated within the normal range throughout the experimental period. Blood serum constituents of experimental animals are shown in tables 1 through 4 below:

\subsubsection{Serum Protein Profile}

Significant $(\mathrm{P} \leq 0.05)$ decline in total protein $(\mathrm{TP})$ levels was observed in G1 goats throughout the experiment compared with normal animals at 0 time. Goats of groups G2 and G3 showed significant decrease in TP levels during the $3^{\text {rd }}$ and $5^{\text {th }}$ weeks PI, values then were elevated at the $7^{\text {th }}$ and $9^{\text {th }}$ weeks to be within the normal range. Values of TP of G4 goats were comparable to normal. Decrease of total protein values were attributable to variations in albumin values as globulin levels of all groups did not record significant differences. A significant $(\mathrm{P} \leq 0.05)$ depression was observed in albumin/globulin ratio (A/G ratio) in $\mathrm{G} 1$ goats on week 3 PI and thereafter, on weeks 3, 5 and 7 PI in G2 and on the $5^{\text {th }}$ week PI in G3 goats compared with comparable 0-time ratios. $\mathrm{A} / \mathrm{G}$ ratios of experimental goats at other times of the experiment were comparable to ratios of 0 times (table 1).

Table 1. Serum protein profile in different groups of goats during the experimental period.

\begin{tabular}{|c|c|c|c|c|c|c|}
\hline \multirow{2}{*}{ Parameters } & \multirow{2}{*}{ Groups } & \multicolumn{5}{|c|}{ Weeks post infection (PI) } \\
\hline & & $\mathbf{0}$ & $3^{\text {rd }}$ & $5^{\text {th }}$ & $7^{\text {th }}$ & $9^{\text {th }}$ \\
\hline \multirow{4}{*}{$\begin{array}{l}\text { Total proteins } \\
(\mathrm{g} / \mathrm{dl})\end{array}$} & G1 & $7.32 \pm 0.12^{b}$ & $6.01 \pm 0.30^{\mathrm{AB}_{\mathrm{a}}}$ & $6.04 \pm 0.20^{A_{a}}$ & $6.23 \pm 0.14^{\mathrm{A}_{\mathrm{a}}}$ & $6.30 \pm 0.16^{\mathrm{Aa}}$ \\
\hline & G2 & $7.45 \pm 0.24^{\mathrm{b}}$ & $6.03 \pm 0.12^{\mathrm{Ba}}$ & $6.04 \pm 0.20^{\mathrm{Aa}}$ & $6.63 \pm 0.21^{\mathrm{ABab}}$ & $6.94 \pm 0.61^{\mathrm{ABab}}$ \\
\hline & G3 & $7.25 \pm 0.36^{\mathrm{b}}$ & $6.48 \pm 0.23^{\mathrm{ABbc}}$ & $6.10 \pm 0.18^{\mathrm{acA}}$ & $6.52 \pm 0.55^{\mathrm{ABab}}$ & $6.79 \pm 0.52^{\mathrm{ABab}}$ \\
\hline & G4 & $7.50 \pm 0.39$ & $7.23 \pm 0.34^{\mathrm{A}}$ & $7.44 \pm 0.10^{\mathrm{B}}$ & $7.56 \pm 0.00^{\mathrm{B}}$ & $7.55 \pm 0.11^{\mathrm{B}}$ \\
\hline \multirow{3}{*}{$\begin{array}{l}\text { Albumin } \\
(\mathrm{g} / \mathrm{dl})\end{array}$} & G1 & $4.07 \pm 0.05^{\mathrm{b}}$ & $2.70 \pm 0.20^{\mathrm{a}}$ & $2.72 \pm 0.19^{\mathrm{Aa}}$ & $2.85 \pm 0.09^{\mathrm{Aa}}$ & $2.88 \pm 0.05^{\mathrm{Aa}}$ \\
\hline & G2 & $4.29 \pm 0.47^{\mathrm{b}}$ & $2.60 \pm 0.25^{\mathrm{a}}$ & $2.54 \pm 0.20^{\mathrm{Aa}}$ & $3.16 \pm 0.21^{\mathrm{ABab}}$ & $3.15 \pm 0.63^{\mathrm{ABab}}$ \\
\hline & G4 & $4.06 \pm 0.45$ & $3.80 \pm 0.42$ & $3.66 \pm 0.07^{\mathrm{B}}$ & $3.88 \pm 0.17^{\mathrm{B}}$ & $3.85 \pm 0.38^{\mathrm{B}}$ \\
\hline \multirow{4}{*}{$\begin{array}{l}\text { Total globulins } \\
(\mathrm{g} / \mathrm{dl})\end{array}$} & G1 & $3.25 \pm 0.14$ & $3.32 \pm 0.38$ & $3.33 \pm 0.19$ & $3.38 \pm 0.33$ & $3.32 \pm 0.23$ \\
\hline & G2 & $3.20 \pm 0.21$ & $3.43 \pm 0.34$ & $3.50 \pm 0.35$ & $3.47 \pm 0.08$ & $3.39 \pm 0.29$ \\
\hline & G3 & $3.47 \pm 0.18$ & $3.56 \pm 0.44$ & $4.20 \pm 0.47$ & $3.62 \pm 0.57$ & $3.62 \pm 0.51$ \\
\hline & G4 & $3.45 \pm 0.13$ & $3.44 \pm 0.11$ & $3.47 \pm 0.19$ & $3.67 \pm 0.17$ & $3.51 \pm 0.18$ \\
\hline \multirow{3}{*}{$\begin{array}{l}\text { Albumin/Globulin } \\
\text { ratio }\end{array}$} & G1 & $1.25 \pm 0.02^{\mathrm{b}}$ & $0.82 \pm 0.08^{a}$ & $0.81 \pm 0.03^{\mathrm{Aa}}$ & $0.87 \pm 0.12^{\mathrm{a}}$ & $0.86 \pm 0.16^{\mathrm{a}}$ \\
\hline & G2 & $1.36 \pm 0.16^{\mathrm{b}}$ & $0.78 \pm 0.11^{\mathrm{a}}$ & $0.72 \pm 0.08^{\mathrm{ACa}}$ & $0.91 \pm 0.17^{\mathrm{ab}}$ & $0.95 \pm 0.23^{\mathrm{ab}}$ \\
\hline & G4 & $1.19 \pm 0.15$ & $1.11 \pm 0.16$ & $1.07 \pm 0.05^{\mathrm{B}}$ & $1.07 \pm 0.09$ & $1.11 \pm 0.15$ \\
\hline
\end{tabular}

Values bearing superscripts A, B, C, D in a column and a, b, c, d in a row differ significantly at $\mathrm{P} \leq 0.05$.

G1: Goats infected- untreated and expressed as control positive.

G2: Goats infected and treated with BAF-EE.

G3: Goats infected and treated with albendazole.

G4: Goats uninfected and dosed with BAF-E E and expressed as control negative.

\subsubsection{Serum Enzymes Activity}

Activities of ALT, AST and yGT elevated significantly in all infected groups (G1, G2 and G3) at the $3^{\text {rd }}$ and $5^{\text {th }}$ weeks PI. At the $7^{\text {th }}$ and $9^{\text {th }}$ weeks PI, activities were still elevated in G1 goats. Activities of yGT were lowered in G2 and G3 goats though still higher than 0 time vales. Activities of ALT and AST in G2 goats were comparable to normal at the $7^{\text {th }}$ and $9^{\text {th }}$ week PI, respectively. Activities of the tested serum enzymes in G4 goats were within normal limits throughout the experiment (table 2). 
Table 2. Serum enzymes activity in different groups of goats during the experimental period.

\begin{tabular}{|c|c|c|c|c|c|c|}
\hline \multirow{2}{*}{ Parameters } & \multirow{2}{*}{ Groups } & \multicolumn{5}{|c|}{ Weeks post infection (PI) } \\
\hline & & $\mathbf{0}$ & $3^{\text {rd }}$ & $5^{\text {th }}$ & $7^{\text {th }}$ & $9^{\text {th }}$ \\
\hline & G1 & $13.43 \pm 0.19^{\mathrm{a}}$ & $16.55 \pm 1.67^{\mathrm{Bb}}$ & $15.04 \pm 0.82^{\mathrm{Bb}}$ & $15.27 \pm 0.28^{\mathrm{Bb}}$ & $16.82 \pm 0.11^{\mathrm{Bb}}$ \\
\hline ALT & G2 & $11.45 \pm 0.63^{\mathrm{a}}$ & $17.02 \pm 0.65^{\mathrm{Bb}}$ & $16.80 \pm 2.32^{\mathrm{Bb}}$ & $14.76 \pm 2.94^{\mathrm{ABab}}$ & $14.11 \pm 2.28^{\mathrm{Aab}}$ \\
\hline \multirow{2}{*}{$(\mathrm{U} / \mathrm{L})$} & G4 & $14.15 \pm 2.69^{\mathrm{b}}$ & $12.83 \pm 1.30^{\mathrm{A}}$ & $11.19 \pm 0.22^{\mathrm{A}}$ & $12.85 \pm 0.16^{\mathrm{A}}$ & $13.45 \pm 2.00^{\mathrm{A}}$ \\
\hline & G1 & $69.09 \pm 0.60^{\mathrm{a}}$ & $107.81 \pm 3.00^{\mathrm{Bb}}$ & $102.14 \pm 2.15^{\mathrm{Bb}}$ & $98.88 \pm 1.01^{\mathrm{Bb}}$ & $102.48 \pm 2.29^{\mathrm{Bb}}$ \\
\hline AST & G2 & $78.89 \pm 0.23^{\mathrm{a}}$ & $102.37 \pm 2.03^{\mathrm{Bb}}$ & $113.61 \pm 2.02^{\mathrm{Bb}}$ & $95.09 \pm 3.48^{\mathrm{Bb}}$ & $84.98 \pm 3.90^{\mathrm{ABab}}$ \\
\hline \multirow{2}{*}{$(\mathrm{U} / \mathrm{L})$} & G4 & $81.47 \pm 4.50$ & $73.61 \pm 0.47^{\mathrm{A}}$ & $64.82 \pm 1.14^{\mathrm{A}}$ & $76.18 \pm 2.83^{\mathrm{A}}$ & $79.51 \pm 1.96^{\mathrm{A}}$ \\
\hline & G1 & $20.33 \pm 0.39^{\mathrm{a}}$ & $30.20 \pm 2.13^{\mathrm{bB}}$ & $30.05 \pm 0.20^{\mathrm{Bb}}$ & $31.86 \pm 0.14^{\mathrm{Bb}}$ & $29.11 \pm 1.55^{\mathrm{bB}}$ \\
\hline$\gamma \mathrm{GT}$ & G2 & $17.59 \pm 1.20^{\mathrm{a}}$ & $26.96 \pm 2.57^{\mathrm{ABb}}$ & $27.48 \pm 2.04^{\mathrm{Bb}}$ & $22.35 \pm 2.37^{\mathrm{Aab}}$ & $19.34 \pm 2.54^{\mathrm{Aa}}$ \\
\hline \multirow[t]{2}{*}{$(\mathrm{U} / \mathrm{L})$} & G3 & $19.50 \pm 0.73^{\mathrm{a}}$ & $28.52 \pm 0.032^{\mathrm{Bb}}$ & $27.37 \pm 0.99^{\mathrm{Bb}}$ & $25.15 \pm 1.55^{\mathrm{Ab}}$ & $24.88 \pm 2.84^{\mathrm{ABb}}$ \\
\hline & G4 & $21.36 \pm 0.85$ & $22.93 \pm 0.89^{\mathrm{A}}$ & $23.75 \pm 0.54^{\mathrm{A}}$ & $23.45 \pm 0.70^{\mathrm{A}}$ & $22.87 \pm 1.05^{\mathrm{A}}$ \\
\hline
\end{tabular}

Values bearing superscripts A, B, C, D in a column and a, b, c, d in a row differ significantly at $\mathrm{P} \leq 0.05$.

G1: Goats infected- untreated and expressed as control positive.

G2: Goats infected and treated with BAF-EE.

G3: Goats infected and treated with albendazole.

G4: Goats uninfected and dosed with BAF-E E and expressed as control negative.

Table 3. Blood serum lipid, T. Bilirubin, urea, creatinine and TAC Profiles in different groups of goats during the experimental period.

\begin{tabular}{|c|c|c|c|c|c|c|}
\hline \multirow{2}{*}{ Parameters } & \multirow{2}{*}{ Groups } & \multicolumn{5}{|c|}{ Weeks Post Infection (PI) } \\
\hline & & $\mathbf{0}$ & $3^{\text {rd }}$ & $5^{\text {th }}$ & $7^{\text {th }}$ & $9^{\text {th }}$ \\
\hline \multirow{4}{*}{$\begin{array}{l}\text { Cholesterol } \\
(\mathrm{mg} / \mathrm{dl})\end{array}$} & G1 & $127.93 \pm 2.61^{\mathrm{a}}$ & $147.75 \pm 4.68^{\mathrm{Bb}}$ & $136.93 \pm 5.35^{\text {Bab }}$ & $146.63 \pm 7.79^{\mathrm{Bb}}$ & $141.81 \pm 4.39^{\mathrm{Ba}}$ \\
\hline & $\mathrm{G} 2$ & $125.92 \pm 5.13^{\mathrm{ac}}$ & $135.01 \pm 6.06^{\mathrm{BCa}}$ & $153.97 \pm 2.44^{\mathrm{Bb}}$ & $99.16 \pm 8.99^{\mathrm{Ac}}$ & $110.02 \pm 9.53^{\mathrm{Aac}}$ \\
\hline & G3 & $115.32 \pm 5.72^{\mathrm{a}}$ & $125.23 \pm 6.24^{\mathrm{ACa}}$ & $146.22 \pm 4.28^{\mathrm{Bb}}$ & $137.99 \pm 3.86^{\mathrm{Bb}}$ & $128.69 \pm 8.81^{\mathrm{ABab}}$ \\
\hline & G4 & $111.46 \pm 11.07$ & $108.11 \pm 7.81^{\mathrm{A}}$ & $110.81 \pm 5.26^{\mathrm{A}}$ & $102.71 \pm 8.84^{\mathrm{A}}$ & $108.27 \pm 7.60^{\mathrm{A}}$ \\
\hline \multirow{3}{*}{$\begin{array}{l}\text { Triglycerides } \\
(\mathrm{mg} / \mathrm{dl})\end{array}$} & G1 & $117.65 \pm 9.59$ & $124.82 \pm 11.91$ & $93.96 \pm 7.93$ & $140.54 \pm 12.00$ & $131.74 \pm 13.84$ \\
\hline & G2 & $128.46 \pm 14.81$ & $134.39 \pm 13.11$ & $129.81 \pm 14.12$ & $76.33 \pm 11.84$ & $89.75 \pm 10.10$ \\
\hline & G4 & $105.49 \pm 5.71$ & $118.17 \pm 11.17$ & $95.00 \pm 14.39$ & $80.22 \pm 12.69$ & $90.72 \pm 16.33$ \\
\hline \multirow{4}{*}{$\begin{array}{l}\text { T. Bilirubin } \\
\text { (mg/dl) }\end{array}$} & G1 & $0.08 \pm 0.04$ & $0.24 \pm 0.03$ & $0.34 \pm 0.14$ & $0.47 \pm 0.16$ & $0.28 \pm 0.15$ \\
\hline & G2 & $0.04 \pm 0.02$ & $0.31 \pm 0.13$ & $0.05 \pm 0.01$ & $0.05 \pm 0.03$ & $0.12 \pm 0.11$ \\
\hline & G3 & $0.06 \pm 0.01$ & $0.23 \pm 0.14$ & $0.13 \pm 0.04$ & $0.42 \pm 0.20$ & $0.21 \pm 0.16$ \\
\hline & G4 & $0.05 \pm 0.01$ & $0.15 \pm 0.08$ & $0.21 \pm 0.06$ & $0.04 \pm 0.02$ & $0.11 \pm 0.08$ \\
\hline \multirow{3}{*}{$\begin{array}{l}\text { Urea } \\
(\mathrm{mg} / \mathrm{dl})\end{array}$} & G1 & $27.90 \pm 1.56^{\mathrm{a}}$ & $46.35 \pm 3.45^{\mathrm{Ab}}$ & $51.60 \pm 3.88^{\mathrm{Bbc}}$ & $60.30 \pm 3.64^{\mathrm{Bb}}$ & $50.54 \pm 2.93^{\mathrm{BCb}}$ \\
\hline & $\mathrm{G} 2$ & $30.00 \pm 2.10^{\mathrm{a}}$ & $31.23 \pm 1.28^{\mathrm{Ca}}$ & $49.60 \pm 1.28^{\mathrm{Bb}}$ & $42.86 \pm 3.01^{\mathrm{ACbc}}$ & $36.43 \pm 4.48^{\mathrm{ACac}}$ \\
\hline & G3 & $34.65 \pm 2.86^{\mathrm{a}}$ & $45.83 \pm 0.18^{\mathrm{Ab}}$ & $51.30 \pm 2.19^{\mathrm{Bb}}$ & $52.65 \pm 3.57^{\mathrm{BCb}}$ & $45.60 \pm 1.46^{\mathrm{BCb}}$ \\
\hline \multirow{4}{*}{$\begin{array}{l}\text { Creatinine } \\
(\mathrm{mg} / \mathrm{dl})\end{array}$} & G1 & $0.26 \pm 0.07^{\mathrm{BCa}}$ & $0.46 \pm 0.04^{\mathrm{Ab}}$ & $0.53 \pm 0.13^{\mathrm{Bbc}}$ & $0.61 \pm 0.05^{\mathrm{Bc}}$ & $0.54 \pm 0.01^{\mathrm{Bc}}$ \\
\hline & G2 & $0.37 \pm 0.13^{\mathrm{Aa}}$ & $0.71 \pm 0.02^{\mathrm{Bb}}$ & $0.66 \pm 0.15^{\mathrm{Bb}}$ & $0.57 \pm 0.05^{\mathrm{Bb}}$ & $0.45 \pm 0.13^{\text {Aac }}$ \\
\hline & G3 & $0.36 \pm 0.05^{\mathrm{Aa}}$ & $0.66 \pm 0.07^{\mathrm{Bb}}$ & $0.53 \pm 0.06^{\mathrm{Bb}}$ & $0.46 \pm 0.04^{\mathrm{Cb}}$ & $0.40 \pm 0.08^{\mathrm{Ab}}$ \\
\hline & G4 & $0.33 \pm 0.10^{\mathrm{AC}}$ & $0.40 \pm 0.14^{\mathrm{A}}$ & $0.35 \pm 0.02^{\mathrm{A}}$ & $0.33 \pm 0.08^{\mathrm{A}}$ & $0.40 \pm 0.10^{\mathrm{A}}$ \\
\hline \multirow{4}{*}{$\begin{array}{l}\text { TAC } \\
(\mathrm{mmol} / \mathrm{L})\end{array}$} & G1 & $0.39 \pm 0.17^{\mathrm{a}}$ & $0.30 \pm 0.04^{\mathrm{Ca}}$ & $0.14 \pm 0.12^{\mathrm{Ab}}$ & $0.22 \pm 0.04^{\mathrm{Ab}}$ & $0.19 \pm 0.10^{\mathrm{Cb}}$ \\
\hline & $\mathrm{G} 2$ & $0.55 \pm 0.09^{\mathrm{a}}$ & $0.20 \pm 0.04^{\mathrm{Bb}}$ & $0.20 \pm 0.14^{\mathrm{Ab}}$ & $0.24 \pm 0.02^{\mathrm{Ab}}$ & $0.39 \pm 0.03^{\mathrm{Ac}}$ \\
\hline & G3 & $0.48 \pm 0.12^{\mathrm{a}}$ & $0.21 \pm 0.13^{\mathrm{Bc}}$ & $0.25 \pm 0.10^{\mathrm{Abc}}$ & $0.28 \pm 0.09^{\mathrm{bcA}}$ & $0.34 \pm 0.02^{\mathrm{Ab}}$ \\
\hline & G4 & $0.45 \pm 0.04^{\mathrm{a}}$ & $0.47 \pm 0.11^{\mathrm{Aa}}$ & $0.51 \pm 0.02^{\mathrm{Ba}}$ & $0.71 \pm 0.09^{\mathrm{Bb}}$ & $0.66 \pm 0.01^{\mathrm{Bb}}$ \\
\hline
\end{tabular}

Values bearing superscripts $\mathrm{A}, \mathrm{B}, \mathrm{C}, \mathrm{D}$ in a column and $\mathrm{a}, \mathrm{b}, \mathrm{c}, \mathrm{d}$ in a row differ significantly at $\mathrm{P} \leq 0.05$.

G1: Goats infected- untreated and expressed as control positive.

G2: Goats infected and treated with BAF-EE.

G3: Goats infected and treated with albendazole.

G4: Goats uninfected and dosed with BAF-E E and expressed as control negative.

\subsubsection{Serum Lipid, T. Bilirubin, Urea, Creatinine and TAC Profiles}

The relevant profiles for the above parameters in all experimental groups are shown in Table 3. Serum cholesterol values in infected-untreated (G1) and infected - BAF EE treated goats showed significant increase from the $3^{\text {rd }}$ week PI and thereafter compared to infected - albendazole treated (G3) and uninfected control goats (G4). At the end of the experiment ( $9^{\text {th }}$ week), cholesterol values in G2, G3 and G4 were within normal levels. No significant difference was observed in triglyceride and total bilirubin levels within and among groups of the experimental animals. Values of serum urea in G1 and G3 goats recorded significant elevation than similar values in G2 and G4 as of the third week PI and onwards till the end of the experiment. Mean levels of creatinine of infected goats of G1, G2 and G3 showed significant increase starting of the $3^{\text {rd }}$ week PI and thereafter to the end of the experiment comparing to 0 -time values. It was observed that values of creatinine at the $3^{\text {rd }}$ and $5^{\text {th }}$ weeks 
were higher than those of the $7^{\text {th }}$ and $9^{\text {th }}$ weeks. Values of creatinine of G4 were within normal levels throughout the experiment. Serum TAC levels were significantly depressed in infected animals of G1, G2 and G3 groups at the $5^{\text {th, }} 7^{\text {th }}$ and $9^{\text {th }}$ weeks PI, while those of G4 animals were elevated from the $3^{\text {rd }}$ week through the $9^{\text {th }}$ week of the experiment compared to 0 -time values.

\subsubsection{Serum Minerals / Electrolytes Level}

Values of blood serum electrolytes / minerals of the experimental groups are shown in Table 4. Mean Ca concentration declined significantly in all infected goats on the $3^{\text {rd }}$ week PI and continued thereafter to the $9^{\text {th }}$ week compared with their 0-time values and values of animals of G4. Calcium concentration in BAF-EE treated animals (G4) remained within normal levels throughout the time of the experiment. No significant differences were observed in serum $\mathrm{P}, \mathrm{Na}, \mathrm{K}, \mathrm{Cl}$ and TIBC levels of all experimental groups, either within different times of the experiment or among the groups.

Table 4. Serum minerals /electrolytes levels in different groups of goats during the experimental period.

\begin{tabular}{|c|c|c|c|c|c|c|}
\hline \multirow{2}{*}{ Parameters } & \multirow{2}{*}{ Groups } & \multicolumn{5}{|c|}{ Weeks Post Infection (PI) } \\
\hline & & $\mathbf{0}$ & $3^{\text {rd }}$ & $5^{\text {th }}$ & $7^{\text {th }}$ & $9^{\text {th }}$ \\
\hline \multirow{4}{*}{$\begin{array}{l}\mathrm{Ca} \\
(\mathrm{mg} / \mathrm{dl})\end{array}$} & G1 & $10.13 \pm 0.06^{\mathrm{b}}$ & $7.99 \pm 0.39^{\mathrm{Aa}}$ & $8.44 \pm 0.29^{\mathrm{Aa}}$ & $8.84 \pm 0.12^{\mathrm{a}}$ & $8.35 \pm 0.24^{\mathrm{Aa}}$ \\
\hline & $\mathrm{G} 2$ & $10.66 \pm 0.16^{\mathrm{b}}$ & $8.63 \pm 0.23^{\mathrm{aA}}$ & $8.13 \pm 0.08^{\mathrm{aA}}$ & $9.31 \pm 0.82^{\mathrm{ab}}$ & $9.18 \pm 0.76^{\mathrm{ABab}}$ \\
\hline & G3 & $11.07 \pm 0.27^{\mathrm{b}}$ & $9.01 \pm 0.01^{\mathrm{ABa}}$ & $8.82 \pm 0.02^{\mathrm{Aa}}$ & $8.78 \pm 0.40^{\mathrm{a}}$ & $9.14 \pm 0.44^{\mathrm{ABa}}$ \\
\hline & G4 & $9.91 \pm 0.70$ & $9.92 \pm 0.09^{\mathrm{B}}$ & $9.92 \pm 0.09^{\mathrm{B}}$ & $9.91 \pm 0.06$ & $10.72 \pm 0.33^{\mathrm{B}}$ \\
\hline \multirow{3}{*}{$\begin{array}{l}\mathrm{P} \\
(\mathrm{mg} / \mathrm{dl})\end{array}$} & G1 & $6.05 \pm 0.62$ & $5.07 \pm 0.41$ & $5.25 \pm 0.48$ & $5.20 \pm 0.50$ & $5.19 \pm 0.60$ \\
\hline & G2 & $5.44 \pm 0.29$ & $4.49 \pm 0.32$ & $4.29 \pm 0.17$ & $5.75 \pm 0.62$ & $5.00 \pm 0.61$ \\
\hline & G4 & $5.07 \pm 0.42$ & $4.83 \pm 0.23$ & $5.44 \pm 0.47$ & $5.64 \pm 0.35$ & $5.25 \pm 0.46$ \\
\hline \multirow{4}{*}{$\begin{array}{l}\mathrm{Na} \\
(\mathrm{mmol} / \mathrm{L})\end{array}$} & G1 & $126.90 \pm 3.47$ & $105.38 \pm 6.39$ & $133.54 \pm 11.33$ & $130.07 \pm 3.83$ & $123.97 \pm 10.92$ \\
\hline & $\mathrm{G} 2$ & $122.99 \pm 6.18$ & $115.40 \pm 6.89$ & $124.64 \pm 8.72$ & $133.04 \pm 10.88$ & $121.51 \pm 12.68$ \\
\hline & G3 & $136.39 \pm 6.39$ & $121.39 \pm 6.21$ & $130.85 \pm 4.29$ & $134.18 \pm 5.85$ & $120.45 \pm 12.86$ \\
\hline & G4 & $125.32 \pm 2.78$ & $123.42 \pm 2.92$ & $129.43 \pm 4.93$ & $121.52 \pm 10.96$ & $129.92 \pm 9.34$ \\
\hline \multirow{2}{*}{$\begin{array}{l}\mathrm{K} \\
(\mathrm{mmol} / \mathrm{L})\end{array}$} & G1 & $4.23 \pm 0.13$ & $4.44 \pm 0.26$ & $5.40 \pm 0.40^{\mathrm{A}}$ & $4.33 \pm 0.48$ & $4.35 \pm 0.62$ \\
\hline & $\mathrm{G} 2$ & $4.32 \pm 0.46$ & $5.51 \pm 0.74$ & $4.95 \pm 0.18^{\mathrm{A}}$ & $4.19 \pm 0.28$ & $4.06 \pm 0.53$ \\
\hline \multirow{4}{*}{$\begin{array}{l}\mathrm{Cl} \\
(\mathrm{mmol} / \mathrm{L})\end{array}$} & G1 & $100.74 \pm 3.14$ & $95.90 \pm 2.21$ & $105.63 \pm 3.33$ & $108.16 \pm 10.22$ & $101.86 \pm 4.45$ \\
\hline & G2 & $104.35 \pm 2.08$ & $100.33 \pm 2.53$ & $103.80 \pm 3.98$ & $107.12 \pm 1.50$ & $103.91 \pm 3.32$ \\
\hline & G3 & $106.93 \pm 0.89$ & $110.28 \pm 4.28$ & $108.73 \pm 0.14$ & $109.29 \pm 1.98$ & $108.81 \pm 1.46$ \\
\hline & G4 & $102.69 \pm 6.17$ & $102.28 \pm 3.01$ & $103.92 \pm 0.47$ & $99.59 \pm 5.71$ & $102.12 \pm 3.79$ \\
\hline \multirow{4}{*}{$\begin{array}{l}\text { TFBC } \\
(\mu \mathrm{g} / \mathrm{dl})\end{array}$} & G1 & $295.29 \pm 17.4$ & $277.57 \pm 20.75$ & $280.29 \pm 17.11$ & $272.34 \pm 20.36$ & $263.87 \pm 37.02$ \\
\hline & $\mathrm{G} 2$ & $260.38 \pm 22.9$ & $245.68 \pm 15.29$ & $258.29 \pm 22.95$ & $256.04 \pm 20.29$ & $232.59 \pm 24.11$ \\
\hline & G3 & $272.13 \pm 26.8$ & $264.33 \pm 19.66$ & $282.97 \pm 19.66$ & $310.27 \pm 21.84$ & $274.92 \pm 42.59$ \\
\hline & G4 & $293.26 \pm 11.1$ & $280.00 \pm 13.11$ & $275.58 \pm 18.13$ & $274.33 \pm 9.83$ & $281.79 \pm 30.89$ \\
\hline
\end{tabular}

Values bearing superscripts A, B, C, D in a column and a, b, c, d in a row differ significantly at $\mathrm{P} \leq 0.05$.

G1: Goats infected- untreated and expressed as control positive.

G2: Goats infected and treated with BAF-EE.

G3: Goats infected and treated with albendazole.

G4: Goats uninfected and dosed with BAF-E E and expressed as control negative.

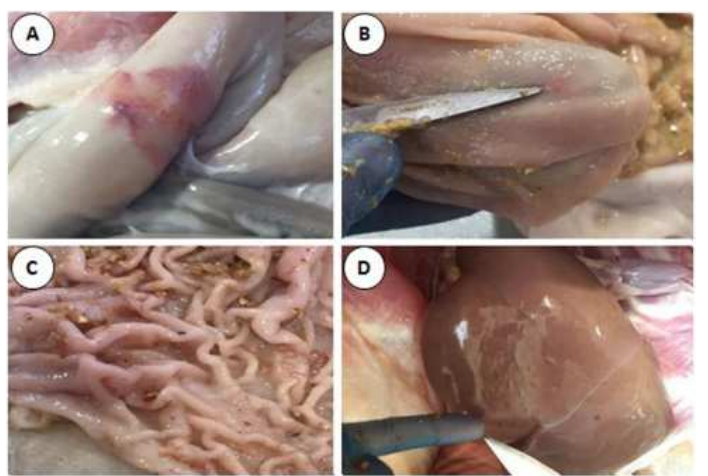

Figure 1. Gross lesions in the abomasum and liver of infected goats: (A \& B) abomasum, (C) abomasal mucosa and (D) liver.

\subsection{Pathological Observations}

\subsubsection{Necropsy Findings}

Infected-untreated group of goats' (G1) carcasses were emaciated and their mucous membranes were pale. The abomasal contents were fluidic, stained dark brown and tinged with bloody flakes with large number of viable actively moving adult $\mathrm{H}$. contortus parasite. The abomasal serosa showed focal ecchymotic hemorrhagic areas (Figure 1A) and the mucosa showed hyperemic mucosal folds with focal ulceration (Figures. 1; B \& C). These changes were more severe in fundic than in cardiac and pyloric areas. The associated lymph nodes were edematous and enlarged in all infected goats. The liver was pale in color and showed focal pale areas of coagulative necrosis (Figure 1; D).

\subsubsection{Microscopic Findings}

\section{(i) Histopathological Alterations in Abomasa}

Abomasa of infected - non-treated goats (G1) showed inflammatory reaction involving different parts of the abomasum. Mucosa of the cardiac region of the abomasum 
revealed focal ulcerations with inflammatory cells' infiltration into the underlying submucosa (Figure 2a). The fundic region showed marked mucosal hypertrophy associated with hyperplastic proliferation of the glands extetending into underlying tissue (Figure 2b). Minute hemorrhages with increase in the depth of gastric pits denoting sites of worms attachment were observed. There was an inflammatory reaction of the mucosa extending into submucosa. The inflammatory cells consisted mainly of eosinophiles mixed with neutrophiles, lymphocytes, and macrophages laden with hemosiderine pigment. Marked goblet cell hyperplasia was noted in the abomasal glandular epithelium. Lesions seen in the pyloric region of the abomasum were marked ulcerations and mucosal inflammation infiltrated mainly with eosinophiles and neutrophiles (Figure 2c).

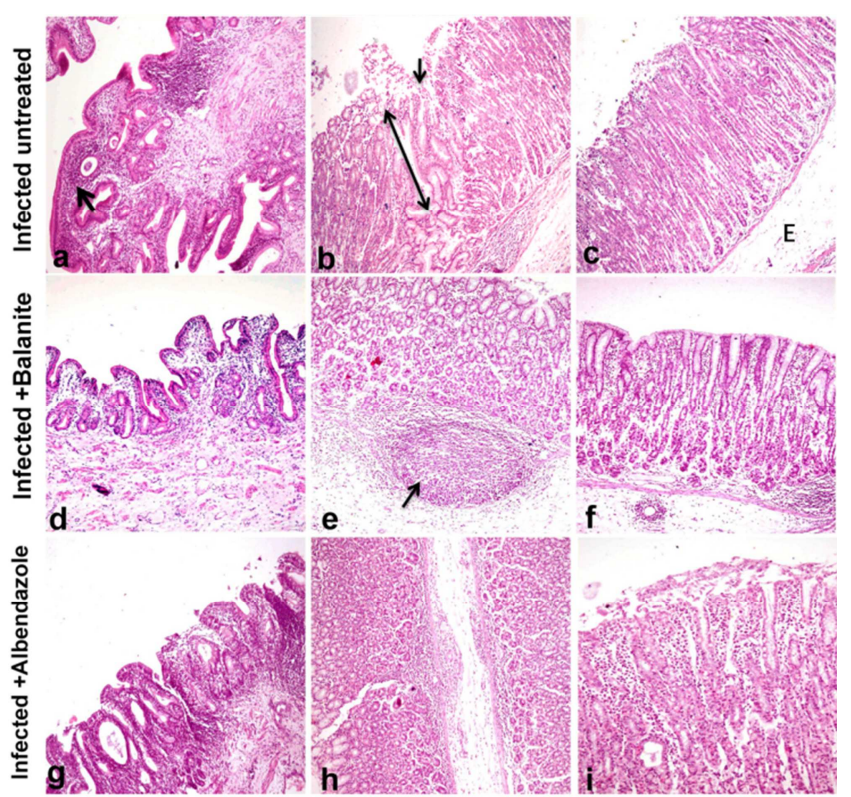

Figure 2. Histological sections of abomasum from experimental goat groups. a) Abomasum (cardiac region) showing mucosal inflammatory cells infiltration associated with hyperplastic proliferation of abomasal glands and dilatation of individual ones (H\&E, x 100). b) Abomasum (fundic region) showing hypertrophy of abomasal mucosa with increased depth of gastric pits and apical minute hemorrhage and marked goblet cells hyperoplasia (H\&E, x 100). c) Abomasum (fundic region) showing denuded gastric mucosa with inflammatory cell infiltration in the lamina propria and marked submucosal edema (H\&E, x100). d) Abomasum (cardiac region) showing a mild inflammatory reaction in mucosal with normal epithelial mucosal lining (H\&E, x100). e) Abomasum (fundic region) showing submucosal lymphoid aggregation (H\&E, x 200). f) Abomasum (pyloric region) showing inflammatory reaction with mucosal and submucosal edema with the presence of perivascular lymphocytic aggregation (H\&E, x100). g) Abomasum (cardiac region) showing mucosal inflammatory cell infiltration with dilatation of abomasal glands (H\&E, x100). h) Abomasum (fundic region) showing mucosal hypertrophy with inflammatory cell infiltration at mucosal base with submucosal edema and inflammatory cells infiltration (H\&E, x40). i) Abomasum (fundic region) showing denuded epithelium with eosinophils infiltration associated with dilated abomasal gland (H\&E, $x 200)$.

Histopathological picture of abomasa of infested - BAFEE treated goats $(\mathrm{G} 2)$ was similar to that of G1 goats, though less severe. Mucosa of the cardiac region of the abomasum showed normal columnar epithelium and there were mild inflammatory cells' infiltration in the submucosa (Figure 2d). The severity of histopathological alterations in the fundic region of this group was the same as G1, but the depth of gastric pits was normal. Mucosal hypertrophy and glandular globlet cells hypeplasia were less than G1 goats. Degenerated larvae surrounded by focal lymphocytic aggregations were detected in the deep fundic region. The inflammatory reaction in the fundic region consisted of mononuclear cells mixed with few neutrophils and there was necrosis of the abomasal glandular epithelium, There was eosinophils' infiltration in the deeper mucosa extended into underlying submucosa. The pyloric part of the abomasum showed moderate inflammation associated with submucosal edema and perivascular lymphocytic aggregation (Figure 2f).

Goats of G3 (infected and albendazole-treated) revealed dilated abomasal glands and the cardiac region showed an inflammatory reaction less than that of the infected group (G1) and more than that of the BAF-EE treated group (G2) (Figure 2g). The fundic area showed hypertrophy, inflammation of mucosa and edema of the submucosa (Figure 2h). Degenerated larvae were observed in the deeper abomasal mucosa with a normal depth of mucosal pits compared with those of G1 goats. The inflammatory cells mainly consisted of eosinophils and macrophages and there was individual necrosis of abomasal glandular epithelium. The pyloric region showed denuded mucosa with the presence of degenerated larvae at the mucosal surface and few eosinophiles inflitration in the mucosa (Figure 2i). Abomasa of G4 goats appeared normal.

\section{(ii) Histological Alterations in Liver}

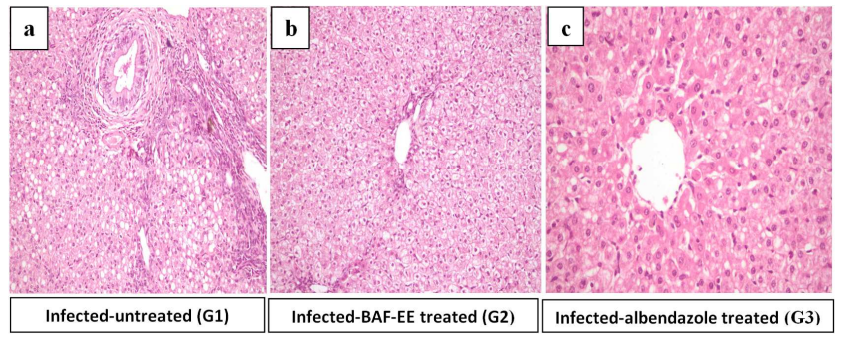

Figure 3. Histological sections of liver and spleen from the experimental goat groups., a) Liver showing portal fibrosis, bile duct hyperplasia with newly formed bile ductules and macrovesicular steatosis of hepatocytes (H\&E, x200). b) Liver showing vacuolization of hepatocytes with normal histological structure of portal area (H\&E x200). c) Liver showing apoptosis of hepatocytes (H\&E, x400).

Liver of G1 goats revealed diffuse macrovesicular steatosis and cholangiohepatitis (Figure 3a). Lesions were characterized by bile duct hyperplasia, portal fibrosis and portal mononuclear cells infiltration and necrosis of hepatocytes associated with oval cell proliferation. Liver of G2 goats revealed vacuolization of hepatocytes and histologically normal portal triad (Figure 3c). Liver of G3 goats showed apoptosis of individual hepatocytes (Figure 3e) with oval cell proliferation. Goats of G4 showed normal histological structure of the portal area. 


\section{Discussion}

Gut parasites induce several functional disturbances in the host body including metabolic changes, weight loss, hematological alterations and increased susceptibility to oxidative stress $[15,39]$. Alteration of serum biochemistry of an infected animal is correlated with the degree of damage and severity of infection [20,49].

The present experiment aimed to evaluate the therapeutic effects of a medicinal plant, B. aegyptiaca fruit's mesocarp ethanolic extract (BAF-EE) in comparison with a common commercial drug, albendazole in haemonchosis experimentally induced in goats. Alterations in blood serum biochemical parameters and pathological changes in abomasa and livers of the goat groups (G1, G2, G3, G4) were studied in four groups of goats: G1 (infected-untreated), G2 (infected-BAF-EE treated), G3 (infected- albendazole treated) and G4 (uninfected-BAF-EE treated) respectively.

Results of serum biochemistry revealed decrease in total protein and albumin values in all infected groups. The decrease continued throughout the experiment in G1 animals and was normalized in G2 and G3 animals towards the end of the experiment. Similar results were obtained by several authors [3, 12, 33, 46, 47, 53, 55]. Worked on haemonchosis in sheep and goat The observed hypoproteinemia may be ascribed to different factors including mal digestion and absorption of food, increased permeability of the abomasal mucosa leading to leakage of plasma, direct blood loss inflicted by the sucking activities of the parasite, bleeding resulted from damage or ulcerations of the abomasal mucosa, stimulation of epithelial cell proliferation and replacement of abomasum acid producing cells by immature cells leading to loss of serum proteins in the gut, and liver damage [13, 24]. Decrease of serum albumin caused reduction of $A / G$ ratio which agrees with the findings of $[33,53]$. Protein values were increased progressively in treated animals two weeks after treatment which indicate improvement by treatment and reduction of worm burden. Our results are similar to those reported by other researchers $[1,3,40]$. Pathological studies performed on the present experimental goats support the observed serum protein changes as there were moving adult $H$. contortus parasite in the abomasa of infected animals and blood tinged fluidal contents indicating hemorrhages from the abomasal mucosa due the sucking habits of $H$. contortus. Histopathological changes of abomasa showed mucosal and submucosal hemorrhages, especially in the untreated goats of G1 followed by both infected-treated groups G2 and G3 which are related directly to the migration of larvae into the pits of gastric glands and also to the physical injury caused by the attachment of adult and pre adult stages of $H$. contortus [11].

Activities of serum enzymes AST, ALT, and $\gamma \mathrm{GT}$ were elevated in infected groups (G1, G2, and G3) from the $3^{\text {rd }}$ week PI, and continued to be elevated to the end of the experiment in G1 and G3 animals while returned to normal level at the end of the experiment in G2 goats. Similar results were reported by a group of researchers $[12,55,59]$ in sheep and goat infected with $H$. contortus as well as in rat infected with $F$. hepatica [41]. Elevation of serum enzymes could be attributed to altered membrane permeability of liver cells which was proven by histopathological examination. Administration of BAF-EE to G2 goats normalized serum enzyme activities which may be attributed to membrane stabilizing effect of BAF-EE due to its content of total phenolics or flavonoids that reduce lipid peroxidation and/or steroids and triterpenoids which have an antioxidant activity [16]. The ethanolic extract of B. aegyptiaca fruits was reported to contain flavonoids, saponins and unsaturated sterols and/or triterpenes [37]. The improvement noticed by the use of $B$. aegyptiaca fruits' mesocarp was attributed to its content of a wide range of biological constituents such as phytoconstituents, crude proteins, carbohydrates, organic acids and vitamin $\mathrm{C}$ as reported [16].

Serum cholesterol values in (G1) and G2 goats showed significant increase from the $3^{\text {rd }}$ week PI and thereafter compared to (G3) and (G4) animals. At the end of the experiment, cholesterol values in groups 2, 3 and 4 were within normal levels, but that of G1 was still high. Elevation of cholesterol in infected animals may be attributed to the parasitic stress resulting in increase of epinephrine and corticosteroids output [24]. Also, it could reflect negative energy balance created by heavy load of parasitic burden leading to enhanced lipolysis [48]. The elevation of serum cholesterol has been reported in buffaloes infected with Toxocara vitulum [30]. The higher levels of urea and creatinine in infected animals suggest impaired regulation of renal tubular transport [32]. It has been reported that the aqueous and ethanolic extracts of $B$. aegyptiaca fruit induce a significant reduction in the levels of serum glucose, total lipids, total cholesterol, triglycerides, transaminases (AST, ALT) and $\gamma$ GT activities in diabetic rats [8].

The significant depression of TAC level observed in sera of infected animals ( G1, G2, and G3) may be attributed to the oxidative stress developed by $H$. contortus. Pivoto et al. [51] determined the total oxidation status and antioxidant capacity of lambs infected with $H$. contortus and reported increased oxidative stress in lambs' sera. On the other hand, increase in levels of Ferric Reducing Ability of Plasma (FRAP), an indicator of TAC in sera of lambs, was observed during infection with $H$. contortus [45]. The authors suggested that TAC increased to minimize the effect of reactive oxygen species (ROS) produced during infection with $H$. contortus. TAC was increased in G4 animals from the $3^{\text {rd }}$ week to the end of the experiment indicating improvement by BAF-EE.

Host reacts against parasites by a number of ways including production of ROS, which play a role in killing or expulsion of parasites from their host [9, 10]. During this defense mechanism, the host may undergo oxidative stress which is developed by imbalance between the generation and removal of ROS within the organism causing damage to biomolecules. Such damage may either be due to depletion of antioxidant defense or increase in ROS production, or both [28].

Serum electrolytes are involved in various fundamental 
physiological processes. In the present experiment, the decrease in serum $\mathrm{Ca}$ level of infected goats may be related to indigestion of $\mathrm{Ca}$ in the abomasa. Radostits et al. [54] stated that presence of $H$. contortus in the abomasum seems to interfere with digestibility of calcium. As most serum $\mathrm{Ca}$ is bound to plasma protein; the resulted hypocalcaemia may also be related to the reported hypoproteinemia. Most of the researchers [3, 33, 55] reported a significant decline in $\mathrm{Ca}$ concentration during $H$. contortus infection in sheep. Other examined serum electrolytes didn't show significant changes during the experiment. Level of TIBC showed no significant variations among or within experimental groups, a result that is in agreement with [43] in ewes infected with gastrointestinal parasites and suffering from anemia.

Histopathological changes noticed in the abomasa of the present goats included mucosal and submucosal hemorrhages and cellular infiltration with inflammatory cells. These findings were obvious in the infected-untreated group, followed by both infected-treated groups. Differences may be due to difference in the number of adult worms found in the abomasa of different groups. The present observations are agreed with the findings reported by earlier workers [3, 64], $[6,18],[47]$ in sheep, goats and rabbits respectively. Histopathological changes seen in the liver were similar to the findings of Dutta et al. [18]. The reaction of the liver in the infected-BAF-EE treated goats was restricted to vacuolization of hepatocytes with histologically normal portal triad which may be due to the hepatoprotective effect of $B$. aegyptiaca extract as described [16, 19, 68].

The observed eosinophilic infiltration is supported with the observation reported in the abomasum of Herrik sheep [64]. Eosinophils are responsible for pathogenesis of parasitic infections and are considered as a first line of defense of the host body against the parasite [7]. Moreover, ovine gastrointestinal nematode infections produce a series of factors that promote eosinophils' migration [67].

\section{Conclusion}

Results of the present study did not show any abnormal behavioral changes and evidence of toxicity during or after treatment with BAF-EE. Also, BAF-EE has hepatoprotective effect and relieves serum biochemical alterations and pathological changes induced by $H$. contortus in goats due to its wide range of biological constituents. The present findings justify the use of this plant as a novel safe natural anthelmintic agent.

\section{Competing Interests}

The author declares that he has no competing interests.

\section{References}

[1] Adam NAM (2006) Effect of piper Abyssinica and Jatropha curcas against experimental Haemochus contortus infection in desert goats. MVSc Thesis University of Khartoum Sudan.
[2] Ahmad A, Anwar-ul-Hassan C, Anwar-ul-Haq A and Majeed MA (1990) Serum proteinogram of lambs experimentally induced Haemonchus contortus infection. Veterinarsk. 60 (4): 195-200.

[3] Albadawi ROE (2010) In vivo and in vitro anthelmintic activity of Balanites aegyptiaca and Artemisia herba Alba on Haemonchus contortus of sheep. PhD Thesis Faculty of Veterinary Science University of Khartoum.

[4] Al-jebory ZE, Al-Khayat DA (2012) Effect of Haemonchus contortus Infection on Physiological and Immunological Characters in Local Awassi Sheep and Black Iraqi Goats. Journal of Advanced Biomedical \& Pathobiology Research 2 (2): 71-80.

[5] Allain CC, Poon LS, Chan CSG, Richmond W, Fu PC (1978) Enzymatic determination of total serum cholesterol. Clinical chemistry 20: $470-475$.

[6] Al-Malki JS (2017) Epidemylogical and histopathological Studies of Haemonchus contortus among goats in Taif KSA. International Journal of Pharmaceutical Research \& Allied Sciences 6 (1): 161-174.

[7] Balic A, Bowles VM, Meeusen ENT (2000) Cellular profiles in the abomasal mucosa and lymph node during primary infection with Haemonchus contortus in sheep. Veterinary Immunology and Immunopathology 75 (1-2): 109-120.

[8] Baragob AEA, AlMalki WH, Shahid I et al. (2014) The hypoglycemic effect of the aqueous extract of the fruits of Balanites aegyptiaca in Alloxan-induced diabetic rats. Pharmacognosy Res 6 (1): 1-5.

[9] Batra S, Srivastava JK, Gupta S, Katiyar JV, Srivastava VML (1993) Role of reactive oxygen species in expulsion of Nippostrongylus brasiliensis from rat. Parasitol 106: 185-192.

[10] Ben-Smith A, Lammas DA, Behnke JM (2002) Effect of oxygen radicals and differential expression of catalase and superoxide dismutase in adult Heligmosomoides polygyrus during primary infections in mice with differing response phenotypes. Parasite Immunol 24: 119-129.

[11] Blood DC, Radostits OM (1989) Veterinary Medicine, A text book of the Disease of cattle, sheep, pigs, Goats and Horses. 7th edition. Bailliere Tindall, Oxford University Press.

[12] Bordoloi G, Jas R, Ghosh JD (2012) Changes in the haematobiochemical pattern due to experimentally induced haemonchosis in Sahabadi sheep. J Parasit Dis 36 (1): 101-105.

[13] Bown MD, Poppi DP, Sykes AR (1991) Nitrogen transactions along the digestive tract of lambs concurrently infected with Trichostrongylus colubriformis and Ostertagia circumcincta. Brit J Nutr 66: 237-249.

[14] Busher JT (1990) Serum Albumin and Globulin. In: HK Walker, WD Hall, JW Hurst (Eds.) Clinical Methods: The History, Physical, and Laboratory Examinations. 3rd edition. Boston: Butterworths Publishers. UK.

[15] Cardia DFF, Rocha-Oliveira RA, Tsunemi MH, Amarante AFT (2011) Immune response and performance of growing Santa Ines lambs to artificial Trichostrongylus colubriformis infections. Vet Parasitol 182 (2-4): 248-258.

[16] Chothani DL, Vaghasiya HU (2011) A review on Balanites aegyptiaca Del (desert date): phytochemical constituents traditional uses and pharmacological activity. Pharmacognosy Reviews 5 (9): 55-62. 
[17] Doumas BT, Waston WA, Bigges HS (1971) Albumin standards and the measurement of serum albumin with bromocresol green. Clinical Chemistry 31: 87-96.

[18] Dutta B, Konch P, Rahman T et al. (2017) Occurrence and pathology of Haemonchus contortus infection in Goats. Journal of Entomology and Zoology Studies JEZS 5 (3): $1284-1287$.

[19] El-Masry SA, Ebeed MM, El-Sayed IH et al. (2010) Protective Effect of Balanites aegyptiaca on Antioxidant Defense System Against Adriamycin-Induced Cardiac Toxicity in Experimental Mice. Egyptian Journal of Biochemistry \& Molecular Biology 28 (1): 101-116.

[20] Esmaeilnejad B, Tavassoli M, Asri-Rezaei S, Dalir-Naghadeh B (2012) Evaluation of antioxidant status and oxidative stress in sheep naturally infected with Babesia ovis. Vet Parasitol 185 (2): $124-130$

[21] Ezzat SM, Motaal AA, El Awdan SAW (2017) In vitro and In vivo antidiabetic potential of extracts and a furostanol saponin from Balanites aegyptiaca. Pharm Biol 55: 1931-1936.

[22] Fairbanks VF, Klee GG (1987) Biochemical aspects of hematology. In: NW Tietz (ed). Fundamentals of clinical chemistry, $3^{\text {rd }}$ ed. Philadelphia: WB Saunders. pp 789-824.

[23] Fossati P, Prencipe L (1982) Serum triglycerides determined colorimetrically with an enzyme that produces hydrogen peroxide. Clin Chem 28: 2077-2080.

[24] Fox MT (1993) Pathophysiology of infection with Ostertagia ostertagi in cattle. Vet Parasitol 46: 143-158.

[25] Gindler EM, King JD (1972) Rapid colorimetric determination of calcium in biologic fluid with Methyl thymol blue. American J Clin Pathol 58: 376-382.

[26] Goodwin JF (1970) Determination of serum phosphorus. Clinical chemistry 16: 776 -780.

[27] Gornall AG, Bardawill CJ, David MM (1949) Determination of serum proteins by means of the biuret reaction. J Biol Chem 177: 751-766.

[28] Halliwell B, Gutteridge JMC (2007) Free Radicals in Biology and Medicine, $4^{\text {th }} \mathrm{ed}$. Oxford Clarendon Press.

[29] Hassan LE, Dahham SS, Saghir SA et al. (2016) Chemo therapeutic potentials of the stem bark of Balanites aegyptiaca (L.) Delile: An antiangiogenic, antitumor and antioxidant agent. BMC Complement Altern Med 16 (396): 1-13.

[30] Hayat CS, Khalid M, Iqbal Z, Akhtar M (1999) Haematological and Biochemical disturbances associated with Toxocara vitulorum infection in buffalo calves. Int J Agric Bio 1 (4): 247-249.

[31] Henary RJ (1964) Clinical Chemistry and Principle Techniques. $1^{\text {st }}$ ed. Harper and Roe, New York.

[32] Hiranyachattada P, Hiranyachattada S, Nualplub S, Pubumpen S, Nontasut P (2000) The effects of Trichinella spiralis infection on renal function in rats. Southeast Asian J Trop Med Public Health 31 (3): 463-466.

[33] Hosseini SH, Khazraiinia P, Zaeemi M, Nematollahi AA (2012) Comparative study on clinical pathology changes in experimentally infected sheep with active and arrested larvae of Haemonchus contortus. Comp Clin Pathol 21: 321-326.
[34] Houot O (1985) Interpretation of Clinical Laboratory Tests (Editorss: G Siest, J Henny, F Schiele, DS Young), Biochemical publications: 220-234.

[35] Hunter AR, Mackenzie G (1982) The pathogenesis of a single challenge dose of Haemonchus contortus in lambs under six months of age. Journal of Helminthology 56 (1): 135-144.

[36] Intisar AMO, Goreish I, Shaddad SA, Elamin TH, Eltayeb IB (2013) Anthelmintic activity of Balanites aegyptiaca against Haemoncus contortus in goats. Journal of Pharmaceutical and Biomedical Sciences 30 (30): 1065-1070.

[37] Jaheed E, Mohamed AH, Hassan NMF, Mahran KMA, Nasr SM, Abou-Zeina HAA (2019) Evaluation of the curative effect of Balanites aegyptiaca fruits ethanolic extract on Haemonchosis experimentally induced in Egyptian Baladi goats: Phytoanalytical, parasitological and hematological studies. $J$ Parasitic Dis [online] Available at: https://doi.org/10.1007/s12639-019-01143-1

[38] Kazmierczak SC, Robertson AF, Catron PA, Briley KP, Kreamer BL, Gourley GR (2002) Direct Spectrophotometric Method for Measurement of Bilirubin in Newborns: Comparasion with HPLC and an Automated Diazo Method. Clinical Chemistry 48 (7): 1096- 97.

[39] Khan MA, Roohi N, Rana MAA (2015) Strongylosis in equines. J Anim Plant Sci 25 (1): 1-9.

[40] Koko WS, Galal M, Khalid HS (2000) Fasciolicidal efficacy of Albizia anthelmintica and Balanites aegyptiaca compared with albendazole. Journal of Ethnopharmacology 71: 247252 .

[41] Kolodziejczyk L, Siemieniuk E, Skrzydlewska E (2005) Antioxidant potential of rat liver in experimental infection with Fasciola hepatica. Parasitol Res 96: 367-372.

[42] Koracevic D, Koracevic G, Djordjevic V, Andrejevic S, Cosic V (2001) Method for the measurement of antioxidant activity in human fluids. J Clin Pathol 54: 356-361.

[43] Kozat S, Yüksek N, Göz Y, Keleş I (2006) Serum iron, total iron-binding capacity, unbound iron-binding capacity, transferrin saturation, serum copper, and hematological parameters in pregnant Akkaraman ewes infected with gastrointestinal parasites. Turk J Vet Anim Sci 30: 601-604.

[44] Liu SJ, Liao ZX, Tang ZS et al. (2017) Phytochemicals and biological activities of Artemisia sieversiana. Phytochem Rev 16: 441-460.

[45] Machado V, Da Silva AS, Schafer AS et al. (2014) Relationship between oxidative stress and pathological findings in abomasum of infected lambs by Haemonchus contortus. Pathol Res Pract 210 (12): 812-817.

[46] Mir RA, Chishti MA, Zargar H, Ganie SA (2007) Clinocopathological changes in sheep experimentally infected with Haemonchus contortus. World J Agric Sci 3: 562-566.

[47] Molina E, González-Redondo P, Moreno-Rojas R et al. (2018) Evaluation of haematological, serum biochemical and histopathological parameters of growing rabbits fed Amaranthus dubius. J Anim Physiol Anim Nutr 102: e525e533.

[48] Murray RK, Granner DK, Mayes PA, Rodwell VW (1990) Harper's Biochemistry, $22^{\text {nd }}$ ed. Prentice Hall, East Norwalk, CT. 
[49] Ortolani EL, Leal MLR, Minervino AHH et al. (2013) Effects of parasitism on cellular immune response in sheep experimentally infected with Haemonchus contortus. Vet Parasitol 196 (1-2): 230-234.

[50] Patton CJ, Crouch SR (1977) Calorimetric determination of urea. Analytical Chemistry 49: 464-469.

[51] Pivoto FL, Torbitz VD, Aires AR et al. (2015) Oxidative stress by Haemonchus contortus in lambs: Influence of treatment with zinc edetate. Res Vet Sci 102: 22-24.

[52] Prophet EB, Mills B, Arrington JB, Sobin LH (1994) Laboratory Methods in Histotecnology. Washington DC: American Registry of Pathology.

[53] Qamar MF, Maqbool A (2012) Biochemical studies and serodiagnosis of haemonchosis in sheep and goats. J Anim Plant Sci 22 (1): 32-38.

[54] Radostits OM, Gay CC, Hinchcliff KW, Constable PD (2007) Veterinary Medicine: A textbook of the diseases of cattle, horses, sheep, pigs and goats (Radostits, Veterinary Medicine) $10^{\text {th }}$ Edition, Saunders, USA.

[55] Rashid S (2016) Biochemical and pathological studies on the gastrointestinal nematode- Haemonchus Contortus. PhD Thesis, Departement of Zoology, Aligarh Muslim Univerity, Aligarh, India.

[56] Reitman S, Frankel S (1957) Colorimetric method for the determination of serum glutamic oxaloacetic and glutamic pyruvic transaminases. Am J Clin Pathol 28: 56 - 63.

[57] Roberts FHS, O'Sullivan PJ (1950) Methods for egg counts and larval cultures for strongyles infesting the gastro-intestinal tract of cattle. Australian Journal of Agricultural Research 1 (1): 99-102.

[58] Schoenfeld RG, Lewellen CJ (1964) A colorimetric method for determination of serum chloride. Clin Chem 10 (6): 533539 .
[59] Sharma DK, Chauhan PPS, Agarwal RD (2001) Changes in the levels of serum enzymes and total protein during experimental haemonchosis in Barbari goats. Small Rumin Res 42: 119-123.

[60] Sharma MC and Joshi C (2002) Serum Mineral and Haematobiochemical Profile of Microfilariae Infected Cattle in India: Its Effects on Production and Therapy. Asian Australas J Anim Sci 15 (3): 357-365.

[61] Snedecor GW, Cochran WG (1982) Statistical methods, $8^{\text {th }}$ ed. Iowa State University USA.

[62] Soulsby EJL (1982) Textbook of Veterinary Clinical Parasitology, $7^{\text {th }}$ ed. Blackwell Scientific Publications Ltd 2425 Broad Street Oxford UK: 231-238.

[63] Szasz G (1969) A kinetic photometric method for serum $\gamma$ glutamyl transpeptidase. Clin Chem 15 (2): 124-136.

[64] Tehrani A, Javanbakht J, Jani M et al. (2012) Histopathological Study of Haemonchus contortus in Herrik Sheep Abomasum. Journal of Bacteriology \& Parasitology 03 (05): 1-5.

[65] Trinder P (1951) A Rapid Method for the Determination of Sodium in Serum. Analyst 76 (907): 596-99.

[66] Wang L, Weller CL (2006) Recent advances in extraction of nutraceuticals from plants. Trends in Food Science and Technology 17 (6): 300-312.

[67] Wildblood LA, Kerr K, Clark OA, Cameron A, Turner OG (2005) Production of eosinophil chemoattractant activity by ovine gastrointestinal nematodes. Veterinary Immunology and lmmunopathology 107: 57- 65.

[68] Yadav JP, Panghal M (2010) Balanites aegyptiaca (L.) Del. (Hingot): A review of its traditional uses, phytochemistry and pharmacological properties. International Journal of Green Pharmacy 4 (3): 140. 